\title{
INFLUENCE OF PROGRAMMED EXERCISE ON THE MOTOR ABILITIES OF PRESCHOOL CHILDREN
}

\author{
Dr. Igor Stanojević, College of professionals studies educators, Aleksinac, Serbia \\ E-mail: stanojevic3@gmail.com
}

ART I C LE IN F O

Original Article

Received: May, 11.2016.

Revised: June, 03.2016.

Accepted: June, 06.2016.

doi:10.5937/IJCRSEE1601055S

UDK

796.012.1-053.4(497.11)

Keywords:

preschool children,

programmed exercise,

motor skills,

multivariate and univariate analysis

of variance.
A B S T R A C T

The research was conducted on a sample of 46 examinees consisting of male children of preschool institutions in Niš, aged five and six \pm 6 months. The main objective of the research was to determine the adaptive processes influenced by programmed exercise on the development of motor skills of preschool children. The aim was to provide the conditions for the establishment of rational procedures for optimal planning, programming and control of the motor exercise of preschool children. The assessment of the examinees was measured by motor tests based on the experience with adult counterparts and modified for young children. The study examined four motor dimensions: agility (running with direction shift), repetitive strength (lateral hops over the rope), flexibility (bend on the bench) and explosive strength (standing long jump). The data obtained by these tests, using the method of multivariate and univariate analysis of variance, showed that at the end of the programmed exercise, there has been a statistically significant increase in motor abilities in the final measurement he initial.

(C) 2016 IJCRSEE. All rights reserved.

\section{INTRODUCTION}

Insufficient motor activity in preschool age adversely affects not only the development of abilities and characteristics, but also the health status of the child. The appearance of flat feet, improper posture, increase of ballast weight, less than optimal cardiovascular system, reduced function of the locomotor system etc. often come as a result of lack of movement. In the later period of a child's life these conditions are manifested by the appearance of a variety of conditions such as hypertension, diabetes, osteoporosis and cardiovascular diseases.

There have been numerous papers that deal with the positive influence of sports on the health of children and youth. Research shows that participation in sports activities contributes to better mental health, increased self-confidence and concentration, reducing the symptoms of depression, stress and anxi-

\section{Corresponding Author}

Dr. Igor Stanojević, College of professionals studies educators, Aleksinac, Serbia

E-mail: stanojevic3@gmail.com

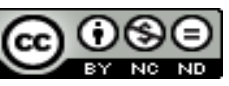

This work is licensed under a Creative Commons Attribution 4.0 International license. The article is published with Open Access at www.ijcrsee.com ety (Findak, 1995; Ismail, 1976; Hraski and Živčić, 1996; Sabo, 2003; Pejčić, 2005; Bala, 2007).

It is well known that children of preschool age who engage in sports activities are more active as young people and adults.

Planning, programming, implementation, evaluation and control of the adaptive process for children in preschool institutions are some of the main tasks of teachers.

Analysis of the impact of exercise on children of preschool age is increasingly becoming the subject of scientific research (Kosinac, 1999; Findak, V. and Delija, K., 2001; Špelić and Božić, 2002; Bala and Popović, 2007; Bala, 2009; Mišigoj-Durakovic, 2008).

In order to successfully analyse the influence of exercise, it is important to resolve the issues of programming and control of instructional methods and the choice of methodological procedures that are suitable for the problem being analysed.

The main objective of the research was to determine the adaptive processes under the influence of programmed exercise on the development of motor skills of preschool children. The realization of such a goal would give us the ability to form rational procedures for optimal planning, programming and control of the motor exercise of children in kindergartens. 


\section{MATERIALS AND METHODS}

The population from which the sample of 46 examinees was taken are male children of preschool institutions in Nis, aged five and six \pm 6 months.

The assessment of the examinees was measured by motor tests based on the experience with adult counterparts and modified for young children (Bala, 2007).

The study examined four motor dimensions: agility (running with direction shiftMTPS), repetitive strength (lateral hops over the rope- MPBK), flexibility (bend on the bench- MPKL) and explosive strength (standing long jump- MSDM).

The tests were defined in the following way:

1) MTPS - running with a change of direction: Two lines are drawn on the ground at a distance of 3 meters. At the signal of the measurer the examinee has to run four times from one line to the other and at each change of direction he has to cross the line marked on the ground with at least one foot. The measured time is from the sign "now" until the moment when the examinee crosses the line marked on the ground for the fourth time. The result is entered in seconds.

2) MPBK - lateral hops over the rope: The examinee stands laterally by the rope that is placed on the ground. At the signal of the measurer he starts jumping laterally with both feet without mid-jump across the rope. The task is performed for 20 seconds. The result of the test is the number of repetitions of the cycle which consists of one hop over the rope and one backwards.

3) MPKL - bend on the bench: The examinee stands on the bench with both feet, raises his arms up and bends down with straight legs towards the measuring tape. The result is entered in centimetres.

4) MSDM - standing long jump: The examinee stands on the mat with both feet and jumps with a swing of his arms. The length of the jump is measured by a tape from the point of jump to the landing point of the back of the foot, and the result is entered in centimetres.

The determination of quantitative differences of motor abilities between the two measurements was performed using the analysis of variance at the multivariate (MANOVA) and univariate level (ANOVA). The processing of the results was performed using the SPSS statistical package, version 6.0.

A multivariate analysis of variance was used in order to examine the global change in the motor abilities of boys between the initial and final measurements, appropriate for dependent results (MANOVA). To test the partial change between the initial and final measurement in the motor abilities of boys we used the results (ANOVA).

The analysis of the results was performed using the SPSS statistical package, version 6.0. With the preschool age children there were measurements of specific motor dimensions at the start of program execution (initial measurement) and at the end (final measurement).

The sports programme which was implemented in kindergartens of the city of Niš was adapted to the abilities and characteristics of preschool children. Special attention was paid to the development of basic motor skills (overcoming space, overcoming obstacles, overcoming resistance and manipulation of objects) and the adoption of specific motor skills in individual sports activities. The exercises included fast running (10 and $20 \mathrm{~m}$ running forward, backward and lateral); exercises with the ball (passing and catching the ball in the movement, keeping a straight line and the curved line with a ball, carrying the ball in a straight line alternating one with the other hand); jumps (standing long jump, running long jump, running long jump across a tape placed at a height of 30 to $40 \mathrm{~cm}$ ). The programme was performed four times a week for 45 minutes in specially prepared areas depending on the material conditions and the use of teaching aids lead by a team of professionals composed of P.E teachers, preschool teachers and pedagogues.

The structure of teaching programmes in this group had a large transformational influence on the development of motor skills and the increase in the level of technical and tactical skills of the examinees.

\section{RESULTS}

Table 1. Multivariate analysis of variance of the motor abilities of the examinees between the initial and the final measurements.

\begin{tabular}{ccc}
\hline Wilks' Lambda & F & P-level \\
\hline .146 & $8.12 .000^{*}$ \\
\hline
\end{tabular}

Table 1 shows the results of testing the significance of the differences in the arithmetic mean of all tests between the initial and the final measurements. It was found that there were statistically significant differences between the initial and final measurements, giv- 
en the level of Wilks' Lambda test (.146) and the size of F-ratio (8.12), as evidenced by the significant differences in the P-level $=.000 *$.

Table 2. Univariate analysis of variance of the motor tests between the initial and the final measurements

\begin{tabular}{crrrrr}
\hline Variable & Measure. & N & Mean & F-test & P-level \\
\hline \multirow{2}{*}{ MTPS } & IN & 46 & 7.54 & \multirow{2}{*}{3.93} & \multirow{2}{*}{$031^{*}$} \\
\cline { 2 - 4 } & FI & 46 & 6.82 & & \\
\hline \multirow{2}{*}{ MPBK } & IN & 46 & 9.24 & \multirow{2}{*}{4.68} & $.000^{* *}$ \\
\cline { 2 - 4 } & FI & 46 & 15.43 & & \\
\hline \multirow{2}{*}{ MPKL } & IN & 46 & 4.28 & \multirow{2}{*}{3.72} & \multirow{2}{*}{$042 *$} \\
\cline { 2 - 4 } & FI & 46 & 9.64 & & \\
\hline \multirow{2}{*}{ MSDM } & IN & 46 & 5.15 & \multirow{2}{*}{5.28} & $.000 * *$ \\
\cline { 2 - 4 } & FI & 46 & 6.32 & & \\
\hline
\end{tabular}

Legend: type of measurement (initial- IN and final- FI), No. of examinees (N), arithmetic mean (Mean), F-ratio value (F-test) and level of its significance (P-level)

Univariate analysis of variance of the motor abilities (Table 2) between the initial and the final measurements indicates that there is a statistically significant difference at the level of .01 in all motor tests, based on the F-test coefficients and their significance (Plevel).

\section{DISCUSSION AND CONCLUSION}

Most of the authors conclude in their works that physical activity of preschool children has a positive impact on reducing obesity, that it helps in building and maintaining muscles and joints and reduces body fat. In addition, children who are physically active have better functional ability and lower blood pressure, lower levels of blood fats and higher cardiorespiratory activity (Bala, 2007).

Early childhood is an extremely important and sensitive developmental period in which the child acquires various experiences. Findak (2001) argues that a child introduces himself to the world around him through movement and establishes communication with the environment which positively affects the development as a whole. For preschool children a biological need for movement and play is particularly emphasized. It happens that some parents neglect these needs, thus depriving children of sensorimotor stimulation, which has a very negative impact on a child's development as a whole.

We cannot talk about the development of certain motor skills at preschool children because their motor functioning is of a general type (Pejčić, 2005; Bala and Popović, 2007). Children react to load with their entire body and overall motor skills. Therefore, when there is impact on a particular motor skill, other capabilities are developed in parallel (Bala and Popović, 2007).

All physical activities with preschool children are best realized through game because it is one of children's primary and natural needs. Children learn about the world through play, learn new moves, fantasize, create, gain friendships and social relationships. It is therefore very important from the earliest days to provide a child with space and time for moving and playing, in order to gain positive habits and a lifelong love for sports.

The research confirmed that there are statistically significant adaptive changes in motor skills under the influence of programmed exercise in examinees of preschool age. It has been proved that with the right intensity, duration and frequency of programmed exercise we can provide an efficient way of continuous improvement of motor abilities.

As an original contribution to science, the research has provided an answer to the question of appropriateness and effectiveness of the implementation of programmed exercise on the motor skills of preschool children.

In recent years, scientists and a significant number of authors have started to pay more attention to preschool children, their lifestyle, diet and motor activities.

\section{ACKNOWLEDGMENTS}

I would like to thank Dr. Igor Petrović for his translation and proofreading services.

Conflict of interests

The author declare no conflict of interest.

\section{REFERENCES}

Bala, G. (2007). Morfološke karakteristike dece predškolskog uzrasta. U G. Bala (Ur): Antropološke karakteristike i sposobnosti predškolske dece. Novi Sad: Fakultet sporta $i$ fizičkog vaspitanja, 31-66.

Bala, G. (2009). Relacije antropoloških karakteristika $i$ sposobnosti predškolske dece. Fakultet sporta i fizičkog vaspitanja Univerziteta u Novom Sadu.

Bala, G. i Popović, B. (2007). Motoričke sposobnosti predškolske dece. U G. Bala (ur.), Antropološke karakteristike i sposobnosti predškolske dece (str. 101-151). Novi Sad: Fakultet sporta i fizičkog vaspitanja.

Findak, V. (1995). Metodika fizičkog i zdravstvenog 
(IJCRSEE) International Journal of Cognitive Research in Science, Engineering and Education Vol. 4, No.1, 2016.

vaspitanja u predškolskom odgoju. Školska knjiga. Zagreb.

Findak, V., \& Delija, K. (2001). Tjelesna i zdravstvena kultura u predškolskom odgoju. Zagreb: Edip.

Hraski, Ž., \& Živčić, K. (1996). Mogućnosti razvoja motoričkih potencijala djece predškolske dobi. U: Fitness, Fakultet za fizičku kulturu Sveučilišta u Zagrebu, Zagrebački velesajam, Zagrebački športski savez, Zagreb.

Ismail, A. H. (1976). Integralni razvoj: Teorija i eksperimentalni rezultati. Kineziologija 1, 2: 6-28, Zagreb.

Kosinac, Z. (1999). Morfološko-motorički i funkcionalni razvoj djece predškolske dobi. Sveučilište u Splitu, Fakultet prirodoslovno-matematičkih znanosti i odgojnih područja u Splitu, str, 69, 90.

Mišigoj-Duraković, M. (2008). Kinanthropometry. Kineziološki fakultet Sveučilišta u Zagrebu.

Pejčić, A. (2005). Kineziološke aktivnosti za decu predškolske i ranog školskog uzrasta. Rijeka. Visoka učiteljska škola u Rijeci.

Sabo, E. (2003). Struktura motoričkog prostora i razlike u motoričkim sposobnostima dečaka predškolskog uzrasta pri upisu u osnovnu školu. Fizička kultura, 56(1-4), 10-17.

Špelić, A., \& Božić, D. (2002). Istraživanje važnosti primjene sportskih programa u predškolskim ustanovama za kasniji razvoj motoričkih sposobnosti. Drugi dani Mate Demarina, 145-154. 